\title{
Prescribed fire effects on dalmation toadflax
}

\author{
JAMES S. JACOBS AND ROGER L. SHELEY ${ }^{1}$
}

\author{
${ }^{l}$ Authors are Research Assistant Professor and Associate Professor, Department of Land Resources and Environmental Sciences, Montana State University, \\ Bozeman, Mont. 59717.
}

\begin{abstract}
Prescribed fires are important for rangeland restoration and affect plant community composition and species interactions. Many rangeland plant communities have been, or are under the threat of noxious weed invasion, however there is little information on how fire effects weeds. Our objective was to determine the effects of prescribed rangeland fire on dalmatian toadflax [Linaria dalmatica (L.) Miller] density, cover, biomass, and seed production. These plant characteristics, as well as density, cover, and biomass of perennial grasses and forbs were measured within burned and adjacent not-burned areas on 3 Artemisia tridentata/Agropyron spicatum habitat types in Montana. Areas were burned in the spring and measured in the fall 1999. Comparisons of plant characteristics between the burned and not-burned sites were made using t-tests and non-parametric Wilcoxon Rank Sum tests. After 1 growing season, fire did not affect density or cover of dalmatian toadflax. Burning increased dalmatian toadflax biomass per square meter at 2 sites, and per plant biomass at all 3 sites. Seed production of dalmatian toadflax was increased by fire at all 3 sites. Fire reduced forb cover at 1 site and increased grass biomass at 2 sites. The increases in dalmatian toadflax biomass and seed production suggest that fire used to restore healthy plant communities may increase dalmatian toadflax dominance. We recommend weed management procedures, such as herbicide control and seeding desirable species, be integrated with prescribed fire where dalmatian toadflax is present in the plant community.
\end{abstract}

Key words: Linarea dalmatica, noxious rangelands weeds, integrated weed management.

Dalmatian toadflax [Linaria dalmatica (L.) Miller] is a rhizomatous, perennial weed native to the Mediterranean region. It was brought to the west coast of North America as an ornamental about 1874 and has spread throughout the western states, British Columbia and Alberta (Alex 1962). Because of high genetic variability, dalmatian toadflax is adapted to a wide variety of habitat conditions but favors well-drained, relatively coarse-textured soils (Lajeunesse 1999). Dalmatian toadflax is an aggressive competitor because of early spring regeneration from vegetative buds on root stocks and rhizomes buried in the soil, and because

Funding for this study was provided by the USDI Bureau of Land Managemen and the Rocky Mountain Elk Foundation. Study sites were contributed by the USDI Bureau of Land Management and USDA Forest Service. Personnel and resources for conducting the burns were contributed by the USDI Bureau of Land Management and USDA Forest Service.

Manuscript accepted 29 May 2002.

\section{Resumen}

Los fuegos prescritos son importantes para la restauración de los pastizales y afectan a la composición de las comunidades de plantas y la interacción entre especies. Muchas comunidades vegetales de pastizal han sido invadidas o están bajo la amenaza de ser invadidas por malezas nocivas, sin embargo, hay poca información sobre como el fuego afecta las malezas. Nuestro objetivo fue determinar los efectos del fuego prescrito en el pastizal sobre la densidad, cobertura, biomasa y producción de semilla de "Dalmatian toadflax" [Linaria dalmatica (L.) Miller]. Estas características de la planta, asi como la densidad, cobertura y biomasa de zacates perennes y hierbas, se midieron dentro de áreas quemadas adyacentes a áreas no quemadas en 3 hábitats del tipo Artemisia tridentata/Agropyron spicatum de Montana. Las áreas fueron quemadas en primavera y medidas en otoño de 1999. Las comparaciones de las características de las plantas entre los sitios quemados y no quemados se realizaron mediante pruebas de $t$ y la prueba no paramétricas de la Suma del Rango de Wilcoxon. Después de una estación de crecimiento, el fuego no afecto la densidad o cobertura del "Dalmatian toadflax". La quema incrementó la biomasa por metro cuadrado de "Dalmatian toadflax" en 2 sitios y la biomasa por planta en los 3 sitios. La producción de semilla de "Dalmatian toadflax" se incremento con el fuego en todos los sitios. El fuego redujo la cobertura de hierbas en un sitio e incremento la biomasa de zacates en 2 sitios. El incremento de biomasa y producción de semilla de "Dalmatian toadflax" sugieren que el fuego utilizado para restaurar comunidades vegetales saludables puede incrementar la dominancia de "Dalmatian toadflax". Nosotros recomendamos que donde el "Dalmatian toadflax" este presente en la comunidad vegetal se integren procedimientos de manejo de maleza, tales como control con herbicidas y siembras de especies deseables, con el fuego

of its high seed production. Infestations of dalmatian toadflax may reduce desirable plants causing loss of winter forage for wildlife (Lajeunesse 1999), reduce cattle-carrying capacity, and reduced appraised ranchland value (Lacey and Olsen 1991). Cattle occasionally browse flowering shoots, but usually avoid this weed (Harris and Carter 1971).

Fire is a natural disturbance of ecosystems that can change community structure and function, at least in the short-term (Ueckert et al. 1978, Sharrow and Wright 1977, Whittaker 1961). Prescribed burning has been used to increase diversity, reduce shrub and tree encroachment, and control excess litter buildup on rangeland for centuries. In most cases, the target species for management with fire have been indigenous, including junipers (Juniperus) and pines (Pinaceae). During the last 50 years, many 
North American rangelands have been invaded by, or are under the threat of invasion by non-indigenous species. There are few studies, however, that quantify the effects of fire on noxious rangeland weeds, and no studies on fire effects on dalmatian toadflax.

Alterations in community structure and function caused by rangeland fire may affect invasibility of an ecosystem or the ability of an existing invader to reach dominant status. On Artemisia steppe communities, establishment of cheatgrass (Bromus tectorum L.) communities can be enhanced by fire. Increased build-up of the continuity of fine fuels from cheatgrass causes self perpetuating, larger, and more frequent fires that favors cheatgrass reproduction and suppresses native perennial grasses (Pellant 1990, Peters and Bunting 1994). A single low intensity fire increased the cover and density of diffuse (Centaurea diffusa Lam.) and spotted knapweeds (C. maculosa Lam.) in northern Washington (Sheley and Roché 1982). In Montana, there is evidence that spotted knapweed increased sixfold within 2 years after a controlled fire on a forested site (Rice and Sacco 1995). Nutrients released from plant litter, and the disturbance created by fire may favor growth and reproduction of weedy species with early germination and rapid growth characteristics (Sheley et al. 1998). The objectives of this study were to determine the short-term effects of a single spring prescribed fire on the cover, density, biomass, and seed production of dalmatian toadflax. We hypothesized that dalmatian toadflax cover, density, biomass and seed production would increase after burning.

\section{Methods}

\section{Study Sites}

The study was conducted within an Artemisia tridentata/Agropyron spicatum (Mueggler and Stewart 1980) habitat type on 3 sites located in the foothills of the Elkhorn Mountains, southeast of Boulder, Mont. The area was managed for elk (Cervus elaphus) range and had not been grazed by livestock for 10 years. Prescribed burns in the area were designed to improve wildlife habitat by creating a diverse mosaic of open parks, and the prescription to burn was based on the presence of woody species. Targeted encroachment tree and shrub species including limber pine (Pinus flexilis James), Rocky Mountain juniper (Juniperus scopulorum Sarg.), Douglas fir
Table 1. Monthly summary from 1998, 1999, and the 30-year average of precipitation (mm) for Elk Horn, Mont., the area of the 3 sites.

\begin{tabular}{lccc}
\hline \hline & 1998 & 1999 & $\begin{array}{c}30 \text { Yr } \\
\text { Average }\end{array}$ \\
\hline January & 6 & 4 & 15 \\
February & 2 & 4 & 9 \\
March & 3 & 1 & 15 \\
April & 12 & 14 & 21 \\
May & 34 & 39 & 47 \\
June & 87 & 65 & 50 \\
July & 32 & 9 & 35 \\
August & 13 & 63 & 35 \\
September & 29 & 6 & 30 \\
October & 9 & 1 & 14 \\
November & 16 & 6 & 13 \\
December & 12 & 4 & 13 \\
Annual & 256 & 214 & 297 \\
\hline
\end{tabular}

(Pseudotsuga menziesii (Mirb.) Franco), big sagebrush (Artemisia tridentata Nutt.) and rubber rabbitbrush (Chrysothamnus nauseosus (Pallas ex Pursh) Britt). Monthly summaries for precipitation in the area encompassing all 3 sites are summarized for the year before the burn (1998), the year of the burn (1999), and the 30 year (1961-1990) average (Table 1).

Site 1 was located in Wood Gulch $\left(46^{\circ}\right.$ $13.002^{\prime} \mathrm{N}, 111^{\circ} 5.094^{\prime} \mathrm{W}$ ) at an elevation of $1,750 \mathrm{~m}$. Slope ranged from 15 to $35 \%$ with a southern aspect. Soils were

Table 2. Plant species present (\% of 40 plots) at Wood Gulch, Upper Horse Gulch and Lower Horse Gulch sites at the time of sampling.

\begin{tabular}{|c|c|c|c|}
\hline Plant species & Wood & Upper Horse & Lower Horse \\
\hline & \multicolumn{3}{|c|}{$\ldots \ldots \ldots$ of 40 plots $) \ldots \ldots \ldots$} \\
\hline Achillea millefolium (L.) & 5 & 23 & 15 \\
\hline Agropyron spicatum (Pursh) Gould & 97 & 100 & 95 \\
\hline Antennaria parvifolia (Nutt.) & 13 & 28 & 15 \\
\hline Arnica diversifolia (Greene) & 0 & 8 & 0 \\
\hline Aristida purpurea (Nutt.) & 3 & 0 & 8 \\
\hline Artemesia tridentata (Nutt.) & 5 & 20 & 3 \\
\hline Astragalus spp. & 0 & 5 & 5 \\
\hline Bouteloua gracilis (H.B.K.) Lag. & 0 & 0 & 5 \\
\hline Chrysothamnus viscidiflorus (Hook) & 13 & 0 & 25 \\
\hline Cirsium undulatum (Nutt.) & 0 & 3 & 3 \\
\hline Erigeron ochroleucus (Nutt.) & 20 & 20 & 5 \\
\hline Festuca idahoensis (Elmer) & 35 & 93 & 60 \\
\hline Juniperus scopulorum (Sarg.) & 0 & 0 & 3 \\
\hline Linaria dalmatica (L.) & 40 & 100 & 60 \\
\hline Linum lewisii (Pursh) & 15 & 18 & 5 \\
\hline Opuntia polyacantha (Haw.) & 0 & 0 & 8 \\
\hline Oryzopsis hymenoides (Roem. and Schult.) & 25 & 10 & 10 \\
\hline Phlox hoodii (Richardson) & 10 & 40 & 15 \\
\hline Poa secunda (Presl) & 80 & 72 & 83 \\
\hline Stipa comata (Trin. and Rupr.) & 5 & 15 & 5 \\
\hline Taraxacum officinale (Weber) & 5 & 8 & 13 \\
\hline Thermopsis montana (Nutt.) & 0 & 3 & 0 \\
\hline Tragopogon dubius (Scop.) & 10 & 43 & 13 \\
\hline
\end{tabular}

Maiden-Lap-rock outcrop complex consisting of loamy-skeletal, carbonatic Typic Calciborolls. The predominant grasses at Wood Gulch were bluebunch wheatgrass (Agropyron spicatum (Prush) Scribn. \& Smith) and Idaho fescue (Festuca idahoensis Elmer). Site 2 was in Upper Horse Gulch $\left(46^{\circ} 12.140^{\prime} \mathrm{N}, 111^{\circ} 55.408^{\prime} \mathrm{W}\right)$ at an elevation of $1,825 \mathrm{~m}$. Slope ranged from 15 to $45 \%$ with an eastern aspect. Upper Horse Gulch soils were Whitcow, Bouldery-Shawmut, very bouldery-rock outcrop complex consisting of loamyskeletal, mixed Typic Argiborolls and loamy-skeletal, carbonatic, frigid Calcic Ustochrepts. Grasses were predominantly bluebunch wheatgrass and prairie Junegrass (Koeleria macrantha (Ledeb.) Schultes). Site 3 was in Lower Horse Gulch $\left(46^{\circ} 13.348^{\prime} \mathrm{N}, 111^{\circ} 55.111^{\prime} \mathrm{W}\right)$ at an elevation of $1,635 \mathrm{~m}$. Slope averaged $15 \%$ and the aspect was southeast. Soils were Windham-Lap very cobbly loams consisting of loamy-skeletal, carbonatic Typic Calciborolls. Grasses were bluebunch wheatgrass, prairie Junegrass, blue grama (Bouteloua gracilis (H.B.K.) Lag. Ex Griffiths), and red threeawn (Aristida prupurea Nutt). Plant species present at the time of sampling for the 3 sites are listed in Table 2.

\section{Experimental Design and Sampling}

The experimental design was a comparison of 2 treatments, burned and not- 
Table 3. Prescribed burn conditions at the 3 sites.

\begin{tabular}{lccccccc}
\hline \hline Site & Size & Date of burn & Wind & Air temp. & RH & $\begin{array}{c}\text { Flame } \\
\text { length }\end{array}$ & $\begin{array}{c}\text { Rate } \\
\text { of spread }\end{array}$ \\
\hline Wood Gulch & (ha) & & $\left(\mathrm{km} \mathrm{hr}^{-1}\right)$ & $\left({ }^{\circ} \mathrm{C}\right)$ & $(\%)$ & $(\mathrm{m})$ & $\left(\mathrm{m}^{2} \mathrm{hr}^{-1}\right)$ \\
Upper Horse Gulch & 80 & $11 / 3 / 99$ & $0-10$ & 14 & $30-80$ & 1.0 & 200 \\
Lower Horse Gulch & 40 & $16 / 3 / 99$ & $0-10$ & 16 & $30-50$ & 1.5 & 250 \\
\hline
\end{tabular}

burned. The burn treatments for the 3 sites are described in Table 3. Comparisons were made by sampling 20 randomly selected $0.44 \mathrm{~m}^{2}$ circular plots within the burns and 20 independent randomly selected plots within immediately adjacent non-burned areas at each of the 3 sites. Soil and species composition in the burned and non-burned areas were identical at each site. Sites were sampled from 29 September through 8 October 1999. The experiment was not replicated in time because of the aggressive herbicide control of the dalmatian toadflax, and therefore it was replicated in space by using 3 sites. All species were counted within sample plots and the area of ground covered by species was visually estimated as a percent of the total area. Each dalmatian toadflax rosette or flowering stem was counted as an individual. Each bunchgrass was counted as an individual. All plants within the circle were then clipped to ground level by species, oven dried $\left(60^{\circ} \mathrm{C}\right)$ to constant weight and weighed. Seed pods of dalmatian toadflax were separated from other vegetative material and seeds were extracted and counted.

\section{Data Analysis}

Sites differed in dalmatian toadflax density and were analyzed separately. Differences between burned and nonburned treatments in density, cover, biomass per square meter, per plant biomass, per plant seed production of dalmatian toadflax, and density, cover and biomass of perennial grass and perennial forbs other than dalmatian toadflax were determined using a 2 sample t-test procedure (SAS Institute Inc. 1990). An F' (folded) statistic was calculated to test for equality of the 2 variances. When normality or equality of variances were not reasonable the non-parametric Wilcoxon Rank Sum test (SAS Institute Inc. 1990).

\section{Results}

\section{Precipitation}

The 30 year average annual precipitation for the area was $297 \mathrm{~mm}$ (Table 1). Annual precipitation in 1998, the year before the prescribed burns was $14 \%$ (Prob. $\mathrm{F} \leq 0.05$ ), data were analyzed using below the 30 -year average and $28 \%$ lower in 1999, the year of the burns. Precipitation during June and August of 1999 were 29 and $79 \%$ above the 30 -year average, for those months, respectively

\section{Density}

Burning did not affect dalmatian toadflax density the season following burning at any of the 3 sites ( $P>0.05$, Table 4$)$. Rosette and mature stem density responses were similar to total density and therefore only total density is presented. At Wood Gulch, dalmatian toadflax was present in $40 \%$ of the plots sampled with mean density of 20 plants $\mathrm{m}^{-2}$ in the burned plots and 43 plants $\mathrm{m}^{-2}$ in the not-burned plots. Dalmatian toadflax was present in $100 \%$ of the plots at Upper Horse Gulch and its density was 141 and 154 plants $\mathrm{m}^{-2}$ in the burned and not-burned plots, respectively. At Lower Horse Gulch, dalmatian toadflax was present in $60 \%$ of the plots sampled with mean density of 30 plants $\mathrm{m}^{-2}$ in the burned plots and 25 plants $\mathrm{m}^{-2}$ in the not-burned plots. There was no difference between the burn treatments in the density of perennial grass or perennial forbs (Table 4).

\section{Cover}

Burning did not affect dalmatian toadflax cover the season following burning at any of the 3 sites ( $P>0.05$, Table 4$)$. At Wood Gulch, dalmatian toadflax cover averaged $2.8 \%$ in the burned plots and $2.2 \%$ in the not-burned plots. Dalmatian

Table 4. Means of density $\left(\mathrm{m}^{-2}\right)$, cover (\%), biomass $\left(\mathrm{m}^{-2}\right.$ and per plant for toadflax), and toadflax seed production (per plant) for dalmatian toadflax, perennial grass, and perennial forbs at Wood Gulch, Upper Horse Gulch and Lower Horse Gulch for the burn and not-burn treatments. Differences between burn and not-burn treatments are indicated by an asterisk before the means.

\begin{tabular}{|c|c|c|c|c|c|c|c|}
\hline Site & Variable & $\begin{array}{l}\text { Toadflax } \\
\text { burn }\end{array}$ & No burn & $\begin{array}{l}\text { Grass } \\
\text { burn }\end{array}$ & No burn & $\begin{array}{l}\text { Forbs } \\
\text { burn }\end{array}$ & No burn \\
\hline$\overline{\text { Wood }}$ & 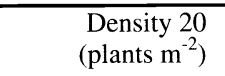 & & 43.0 & 180.0 & 202.0 & 22.0 & 23.0 \\
\hline Wood & Cover $(\%)$ & 2.8 & 2.2 & 25.4 & 23.9 & 1.9 & 2.8 \\
\hline Wood & Biomass $\left(\mathrm{g} \mathrm{m}^{-2}\right)$ & 17.0 & 8.0 & $* 70.5$ & $* 40.0$ & 2.4 & 4.9 \\
\hline Wood & $\begin{array}{r}\text { Per plant biomass } \\
\qquad\left(\mathrm{g} \text { plant }^{-1}\right)\end{array}$ & $* 4.2$ & $* 1.0$ & & & & \\
\hline Wood & $\begin{array}{r}\text { Seed production } \\
\left(\text { no. plant }{ }^{-1}\right)\end{array}$ & $* 355.0$ & $* 7.0$ & & & & \\
\hline Upper Horse & Density & 141.0 & 154.0 & 142.0 & 130.0 & 63.0 & 60.0 \\
\hline Upper Horse & Cover & 7.8 & 6.2 & 23.1 & 25.3 & 5.9 & 2.9 \\
\hline Upper Horse & Biomass & $* 53.0$ & $* 31.0$ & 28.9 & 48.4 & 8.6 & 16.2 \\
\hline Upper Horse & Per plant biomass & $* 7.1$ & $* 1.1$ & & & & \\
\hline Upper Horse & Seed production & $* 158.0$ & *79.0 & & & & \\
\hline Lower Horse & Density & 30.0 & 25.0 & 177.0 & 172 & 36.5 & 18.5 \\
\hline Lower Horse & Cover & 5.7 & 2.7 & 24.9 & 21.9 & 7.6 & 4.4 \\
\hline Lower Horse & Biomass & $* 38.0$ & $* 8.0$ & $* 73.0$ & $* 45.0$ & 20.7 & 16.3 \\
\hline Lower Horse & Per plant biomass & $* 7.3$ & $* 2.0$ & & & & \\
\hline Lower Horse & Seed production & $* 1,328.0$ & $* 29.0$ & & & & \\
\hline
\end{tabular}


toadflax cover at Upper Horse Gulch was 6.2 and $7.8 \%$ in the not-burned and burned plots, respectively. Cover at Lower Horse Gulch averaged 2.7 and $5.7 \%$ in the notburned and burned plots, respectively. Burning did not affect perennial grass cover at any site. Perennial forb cover was reduced by burning from $5.9 \%$ in the plots that were not burned to 2.8 in the burned plots at Upper Horse Gulch (Table 4).

\section{Biomass}

The influence of fire on dalmatian toadflax biomass per square meter varied depending on site (Table 4). At Wood Gulch where dalmatian toadflax was absent from $60 \%$ of the plots, the fire effect was not significant even though the biomass was twice as high on plots that burned $\left(17 \mathrm{~g} \mathrm{~m}^{-2}\right)$ compared to those that did not $\left(8 \mathrm{~g} \mathrm{~m}^{-2}\right)$. On Upper Horse Gulch where dalmatian toadflax occurred on all plots, fire increased dalmatian toadflax biomass from $31 \mathrm{~g} \mathrm{~m}^{-2}$ where there was no fire to $53 \mathrm{~g} \mathrm{~m}^{-2}$ where there was fire. Fire increased dalmatian toadflax biomass from 8 to $38 \mathrm{~g} \mathrm{~m}^{-2}$ on the not-burned plots compared to burned plots at Lower Horse Gulch where dalmatian toadflax occurred on $60 \%$ of the plots.

Fire increased dalmatian toadflax per plant biomass at all sites (Table 4). At Wood Gulch, dalmatian toadflax biomass was $1.0 \mathrm{~g}$ per plant in the plots that were not burned and $4.2 \mathrm{~g}$ per plant in the burned plots. Dalmatian toadflax increased from 1.1 to $1.7 \mathrm{~g}$ per plant in the notburned and burned plots, respectively, at Upper Horse Gulch. Dalmatian toadflax biomass in the not-burned plots at Lower Horse Gulch was $2.0 \mathrm{~g}$ per plant compared to $7.3 \mathrm{~g}$ per plant in the burned plots.

Fire increased perennial grass biomass at Wood and Lower Horse Gulches, but there was no difference at Upper Horse Gulch. Perennial grass biomass production at Wood Gulch was $40.8 \mathrm{~g} \mathrm{~m}^{-2}$ where there was no burning and $70.5 \mathrm{~g} \mathrm{~m}^{-2}$ where it was burned. Upper Horse Gulch perennial grass biomass was 28.9 and $48.4 \mathrm{~g} \mathrm{~m}^{-2}$ in the burned compared to not-burned plots, respectively. At Lower Horse Gulch, perennial grass biomass increased from 45.1 to $73.0 \mathrm{~g} \mathrm{~m}^{-2}$ in the not-burned compared to the burned treatments. Fire did not affect perennial forb biomass (Table 4).

\section{Dalmatian Toadflax Seed Production}

Burning dramatically increased dalmatian toadflax seed production per plant at all 3 sites (Table 4). Burning increased seed production from 7 to 355 seeds per plant at Wood Gulch, from 79 to 158 seeds per plant at Upper Horse Gulch, and from 29 to 1,328 seeds per plant at Lower Horse Gulch.

\section{Discussion}

It is not surprising that there was no short-term burning effect on dalmatian toadflax, perennial grass, or perennial forb density. The heat intensities of the burns at the 3 sites were considered normal for spring fires by technicians conducting the burns (USDA Forest service, personal communication). Many bunchgrass clumps and dalmatian toadflax rosettes were still green after burning and dalmatian toadflax rhizomes were generally below $10 \mathrm{~mm}$ of soil and not damaged by fire generated heat (Hayward 1938). It is doubtful that the thermal death point for plant tissue was reached during the fires (Write 1970, Wright et al. 1976).

Maximum temperatures in shrubland fires are always near the top of the vegetation (Bailey and Anderson 1980, Whittaker 1961), killing shrub and tree species with perennating buds in this zone. The removal of big sagebrush and pine species by the prescribed burns in this study opened niches once occupied by these species and made available resources they used. The reduced competition for resources could partly explain the increase in biomass of dalmatian toadflax and perennial grass, and the increased seed production of dalmatian toadflax in the burned areas. We expect future increases of dalmatian toadflax because large areas once occupied by trees and shrubs were left open to invasion by high seed producing dalmatian toadflax especially on the Upper Horse Gulch site where there were fewer perennial grasses to fill open niches. On semi-arid rangelands, nutrients bound in living and dead biomass are made available for plant growth by fire (DeBano and Conrad 1978). In addition, soil conditions after burning often favor nitrification (Sharrow and Wright 1977). Increases in dalmatian toadflax and grass biomass in the burned areas may have occurred because of increased nutrients. On a different burn under similar conditions, nitrate increased $(\mathrm{P}=0.002)$ from $3.3 \mathrm{mg} \mathrm{kg}^{-1}$ on plots that did not burn to $7.6 \mathrm{mg} \mathrm{kg}^{-1}$ on plots that burned (Jacobs unpublished data). This offers another explanation to the increase in dalmatian toadflax and grass biomass in the burned areas. The lack of grass response at Upper Horse Gulch suggests that there was less grass present to respond to increased nutrients, or dalmatian toadflax was dense enough to overwhelm the grass. Nitrate is mobile and rapidly used by plants and therefore high nitrate conditions may favor weeds with early and rapid growth characteristics (Sheley et al. 1998) over native grasses that tend to have less aggressive growth characteristics.

The more robust dalmatian toadflax plants produced 2- to 10 -fold more seeds in the burned areas compared to areas notburned. While we did not detect increases in dalmatian toadflax density in the season following fire, increased seed production suggests that we can expect increases in toadflax density and spread on these sites in the future. Increases in the density of other invasive non-indigenous species have been reported. Sheley and Roché (1982) found increased cover and density of diffuse and spotted knapweeds in northern Washington, and Rice and Sacco (1995) report a sixfold spotted knapweed increase in Montana within 2 years after a controlled fire on a forested site.

\section{Conclusions}

Our results suggest fire will not reduce dalmatian toadflax populations on rangeland and may increase the dominance of this weed. We recommend implementing an integrated dalmatian toadflax management program when conducting a prescribed burn for restoring native plant communities and controlling encroaching undesirable plants. Integrated practices could include herbicide application to reduce dalmatian toadflax density and seed production, and seeding with desirable plant species to fill niches opened by fire.

\section{Literature Cited}

Alex, J.F. 1962. The taxonomy, history, and distribution of Linaria dalmatica. Can. J. Bot. 40:295-307.

Bailey, A.W. and M.L. Anderson. 1980. Fire temperatures in grass, shrub, and aspen forest communities of Central Alberta. J. Range Manage. 3:37-40.

DeBano, L.F. and C.E. Conrad. 1978. The effect of fire on nutrients in a chaparral ecosystem. Ecol. 59:489-497.

Harris, P. and A.C. Carter. 1971. Linaria vulgaris mill., yellow toadflax, and L. dalmatica (L.) Mill., broad-leaved toadflax (Scrophulariaceae). In: Biological control programmes against insects and weeds in Canada 1959-1968. Commonwealth Agr. Bureaux, Slough, England. 94-97. 
Hayward, F. 1938. Soil temperatures during forest fires in longleaf pine region. J. For. $36: 478-491$.

Lacey, J. and B. Olsen. 1991. Environmental and economic impacts of noxious rangeland weeds. In: L.F. James, J.O. Evans, M.H. Ralphs, R.D. Child (eds.) Noxious Rangeland Weeds. Westview Press, Boulder, Colo. 5-16.

Lajeunesse, S. 1999. Dalmatian and Yellow Toadflax. In: Sheley, R.L. and J.K. Petroff (eds.). Biology and Management of Noxious Rangeland Weeds. Oregon State Press, Corvallis, Ore.. p.249-260.

Mueggler, W.F. and W.L. Stewart. 1980. Grassland and shrubland habitat types of Western Montana. Intermountain Forest and Range Experiment Station. USDA-FS. Ogden, Utah. 154 pp.

Pellant, M. 1990. The cheatgrass-wildfire cycle-are there any solutions? In: E.D. McArthur, E.M. Romney, S.D. Smith, and P.T. Tueller (eds.) Proc. Symp. on cheatgrass invasion, shrub die-off, and other aspects of shrub biology and management. USDA For. Ser. Gen. Tech. Rep. INT-276, 11-18.
Peters, E.F. and S.C. Bunting. 1994. Fire conditions pre- and postoccurrence of annual grasses on the Snake River Plain. In: S.B. Monson and S.G. Kitchen (eds.) Proc. Ecology and management of annual rangelands. USDA For. Ser. Gen. Tech. Rep. INTGTR-313, 31-36.

Rice, P. and R. Sacco. 1995. Appendix E. Spotted knapweed response to Burning. Manuscript. Division of Biology, University of Montana, Missoula. p. 100-102.

SAS Institute Inc. 1990. SAS/STAT user's guide, ver 6. Vol. 2. Cary, NC. 920 p.

Sharrow, S.H. and H.A. Wright. 1977. Effects of fire, ash, and litter on soil nitrate, temperature, moisture and tobosagrass production in the Rolling Plains. J. Range Manage. 30:266-270.

Sheley, R.L. and BF. Roché, Jr. 1982. Rehabilitation of spotted knapweed infested rangeland in northeastern Washington. Abstr. of papers, W. Soc. Weed Sci., Denver, Colo.

Sheley, R.L., J.S. Jacobs, and M.L. Carpinelli. 1998. Distribution, biology, and management of diffuse (Centaurea diffusa) and spotted knapweed (Centaurea maculosa). Weed Technol. 12:353-362.
Ueckert, D.N., T.L. Whigham, and B.M. Spears. 1978. Effect of burning on infiltration, sediment, and other soil properties in a mesquite-tobosagrass community. J. Range Manage. 31:420-425.

Whittaker, E. 1961. Temperature in heath fires. J. Ecol. 49:709-715.

Write, H.A. 1970. A method to determine heat-caused mortality in bunchgrass. Ecol. 51:582-587.

Wright, H.A., S.C. Bunting, and L.F. Neunschwander. 1976. Effect of fire on honey mesquite. J. Range Manage. 29:467-471. 